\title{
Faktor Penentu Preferensi Tipe Hunian di Kalangan Mahasiswa
}

\author{
Imega Reski ${ }^{1}$ dan Angela Christysonia Tampubolon ${ }^{2}$ \\ ${ }^{1}$ Mahasiswa Program Studi Magister Arsitektur, SAPPK, Institut Teknologi Bandung \\ ${ }^{2}$ Asisten Peneliti Program Studi Magister Arsitektur, SAPPK, Institut Teknologi Bandung \\ imegareski18@gmail.com
}

\begin{abstract}
ABSTRAK
Perkembangan perguruan tinggi di Indonesia berimplikasi pada peningkatan jumlah mahasiswa. Kecenderungan mayoritas jumlah mahasiswa yang merupakan transmigran pada daerah perguruan tinggi terkait berimplikasi lebih lanjut pada peningkatan kebutuhan hunian. Perbedaan latar belakang menimbulkan karakteristik kebutuhan hunian yang berbeda-beda pula. Muncullah beberapa tipe hunian dengan ciri khasnya masing-masing. Penelitian ini membagi hunian menjadi tujuh tipe, yaitu rumah orang tua, rumah kerabat, rumah beli, apartemen, indekos, kontrakan, dan asrama. Penelitian ini mencoba untuk menelaah faktor-faktor preferensi tipe hunian, mencari faktor yang menjadi pembeda utama dari preferensi tersebut, serta membandingkan penilaian tingkat kepentingan responden terhadap setiap faktor kunci di setiap tipe hunian. Hal ini dapat bermanfaat dalam penyediaan hunian mahasiswa yang lebih tepat guna sesuai karakteristik utama pembeda tipe hunian tersebut. Pengumpulan data dilakukan dalam dua tahap. Hasil analisis data tahap pilot dianalisis secara kualitatif dan menjadi kerangka kuesioner tahap dua. Data pada penelitian eksploratif ini kemudian dianalisis secara kuantitatif menggunakan analisis faktor dan ANOVA. Hasil penelitian menunjukkan bahwa terdapat 14 faktor preferensi tipe hunian dengan empat faktor kunci preferensi yang memiliki perbedaan penilaian tingkat kepentingan yang signifikan pada setiap tipe hunian yaitu kemandirian, interaksi sosial, kebebasan, dan privasi. Diagram perbedaan tingkat kepentingan faktor kunci pada masing-masing tipe hunian disajikan dalam artikel ini.
\end{abstract}

Kata kunci: faktor penentu, mahasiswa, preferensi, tipe hunian

\section{ABSTRACT}

The universities development in Indonesia has implications on the increasing number of students. The tendency of the students majority who are transmigrants in the relevant college areas has further implications on the increasing need of shelter. Different backgrounds made different needs. Thus, there are several types of dwellings with their own characteristics. This study divides the dwellings into seven types, namely parents' house, relatives' house, bought house, apartment, unit rented house, rented house and dormitory. This study attempts to examine dwelling type preference factors. This study also attempts to find the key factors that became the main preference differentiators, and also comparing the respondent's importance level to each key factor on each dwelling type. The data were collected through a two-stage questionnaire. The results of the pilot phase questionnaire were analyzed qualitatively and became the framework of second phase questionnaire. The exploratory research data were then analyzed quantitatively using factor analysis and ANOVA. The results showed that there were 14 dwelling type preference factors with four preference key factors which differed significantly on the importance level valuation of each dwelling type, namely independency, social interaction, freedom, and privacy. The key factors' importance level diagram on each dwelling types is served.

Keywords: college students, key factor, occupancy type, preference 


\section{Pendahuluan}

Peningkatan jumlah mahasiswa akan berimplikasi lebih lanjut terhadap peningkatan kebutuhan hunian di sekitar perguruan tinggi terkait. Salah satu penyebabnya adalah dengan adanya sejumlah mayoritas mahasiswa yang bukan berasal dari daerah domisili perguruan tinggi terkait atau merupakan transmigran. Rugg (dalam Nurdini, 2012) menyatakan bahwa mahasiswa memiliki kondisi berhuni yang sementara pada suatu lokasi sebagai bagian dari siklus hidup kaum muda dalam fase meninggalkan orang tua dengan motif pendidikan. Kondisi ini menjadikan mahasiswa menarik untuk dijadikan objek penelitian terkait preferensi hunian, khususnya selama masa studi.

Perbedaan latar belakang, khususnya sosio-demografis dan nilai, memberikan perbedaan terhadap preferensi kebutuhan setiap mahasiswa (Nijenstein, Haans, Kemperman, dan Borgers, 2015). Selain itu, Khozaei, Hassan, Al Kodmany, dan Aarab (2014) menyatakan bahwa perbedaan preferensi dan kebutuhan juga dapat didasari oleh perbedaan jenis kelamin, asal daerah, dan tingkat studi. Hal ini menyebabkan pemenuhan hunian ini kemudian muncul dalam berbagai tipologi dengan ciri khas masing-masing. La Roche, Flanigan, dan Copeland (2010) menyatakan bahwa pemberian pilihan hunian berdasarkan preferensi mahasiswa merupakan hal penting, terutama dengan adanya perubahan tren dan kebutuhan dari masa ke masa. Khozaei, Ramayah, Hassan, dan Surienty (2012) juga menyatakan hal tersebut penting karena keterpenuhan preferensi akan berpengaruh terhadap keterikatan mahasiswa dengan tempat yang ditinggalinya, sehingga akan menimbulkan kebetahan. Selain itu, tipe hunian sendiri juga dapat dijadikan sebagai pembeda pasar (La Roche, Flanigan, dan Copeland, 2010). Oleh karena itu, penelitian mengenai faktor preferensi ini menjadi penting untuk dilakukan dalam melihat pembeda utama dari kepentingan mahasiswa dalam memilih tipe hunian selama masa studi. Hal ini dapat membantu penyedia hunian untuk menyesuaikan fasilitas dan sasaran sesuai dengan tipe hunian yang ingin dikembangkan.

Penelitian ini membagi tipe hunian ke dalam dua kategori besar yaitu hunian milik dan hunian sewa. Hunian milik didefinisikan sebagai hunian dengan hak milik yang dipegang baik oleh mahasiswa itu sendiri sebagai penghuni maupun kerabat mahasiswa. Sehingga, peneliti membagi lagi kategori hunian milik menjadi rumah beli, rumah orang tua, rumah kerabat, dan apartemen. Sementara, hunian sewa adalah bangunan hunian yang disewakan sebagian atau seluruhnya oleh pemilik kepada pengguna (Nurdini, 2012).

Dalam penelitiannya, Nurdini (dalam Sakina dan Kusuma, 2016) membagi hunian sewa ke dalam empat tipe berdasarkan proses pengadaannya yaitu rumah, paviliun, indekos, dan apartemen. Rumah didefinisikan sebagai bangunan hunian milik yang disewakan sebagian atau seluruhnya oleh pemilik kepada pengguna. Paviliun didefinisikan sebagai bangunan tambahan yang dibangun pada kavling yang sama dengan hunian pemilik untuk disewakan. Indekos didefinisikan sebagai bangunan yang dibangun pada kavling tersendiri yang khusus untuk disewakan. Sedangkan, apartemen merupakan sebuah bangunan hunian vertikal yang terdiri atas unit hunian berupa kamar dan fasilitas pendukung.

Dari referensi tersebut, peneliti memindahkan apartemen ke dalam kategori hunian milik karena sifatnya yang dapat dimiliki oleh penghuni. Selanjutnya, dalam penelitian ini, peneliti lebih melihat pendefinisian tipologi hunian sewa berdasarkan satuan unit yang disewakan. Sehingga, peneliti membagi kategori hunian sewa menjadi indekos, kontrakan, dan asrama. Dalam hal ini, indekos didefinisikan sebagai hunian dengan unit sewa berupa kamar dan fasilitas bersama. Kontrakan didefinisikan sebagai hunian dengan unit sewa berupa rumah yang dapat disewa oleh satu atau beberapa orang sekaligus secara bersama-sama. Rumah dan paviliun pada referensi sebelumnya 
dapat dikategorikan ke dalam indekos atau kontrakan pada penelitian ini berdasarkan satuan unit yang disewakan. Berdasarkan satuan unit sewa, asrama memiliki kesamaan dengan indekos. Perbedaannya terletak pada adanya kecenderungan keterkaitan asrama dengan suatu program khusus. Selain itu, pada asrama umumnya terdapat keharusan untuk berbagi kamar dengan satu atau lebih penghuni asrama lain. Sementara, pada indekos, hal tersebut lebih dibebaskan kepada kehendak pengguna.

Berbagai penelitian terkait perilaku dalam arsitektur telah dilakukan untuk menelaah preferensi manusia terkait hunian. Kriteria hunian ideal yang cukup dominan dari beberapa hasil penelitian adalah terkait kondisi lingkungan alami, suasana, kelengkapan fasilitas, interaksi sosial, dan desain arsitektural (Abdassah, Anandhita, dan Sesotyaningtyas, 2013; Andoni dan Kusuma, 2016; Muchlis dan Kusuma, 2016;Putra, Widyasanti, dan Natasya, 2013;). Secara khusus, Sakina dan Kusuma (2015) mengemukakan bahwa tingkat kepuasan mahasiswa terhadap hunian sewa dipengaruhi oleh faktor-faktor lokasi, biaya, kelengkapan fasilitas, dan kondisi lingkungan. Terkait faktor lingkungan, secara lebih rinci, Adrian (2015) menyatakan kriteria lingkungan hunian yang ideal dapat dinilai dari faktor aksesibilitas, kelengkapan prasarana dan utilitas pendukung, serta karakter pembentuk ruang. Dalam lingkup yang lebih kecil, Rachman dan Kusuma (2016) membahas faktor-faktor penyebab kebetahan di dalam kamar sebagai ruang hunian paling intim. Faktor-faktor tersebut adalah kelengkapan fasilitas, desain arsitektural, dan privasi. Selain hunian secara umum, beberapa penelitian juga telah mencoba menelaah faktor-faktor preferensi terhadap apartemen sebagai salah satu tipe hunian. Faktor-faktor preferensi apartemen yang cukup dominan dari beberapa hasil penelitian adalah investasi, lokasi, aksesibilitas (Cahyani P., Ilhamdaniah, dan Indra K.D., 2012; Catalonia, 2016; Kartamihardja, 2015), kelengkapan fasilitas (Cahyani P., Ilhamdaniah, dan Indra K.D., 2012; Catalonia, 2016), kepraktisan, gaya hidup, dan privasi (Kartamihardja, 2015).

Penelitian ini mengembangkan hasil telaah kecenderungan alasan tertentu secara menyeluruh terhadap tipe hunian tertentu. Penelitian ini mencoba untuk mencari faktor utama yang menjadi pembeda dalam menentukan preferensi tipe hunian di kalangan mahasiswa. Peneliti menyadari akan adanya pengaruh latar belakang subjek terhadap preferensi. Namun, fokus penelitian ini akan mencoba untuk melihat gambaran umum faktor utama preferensi dari berbagai jenis latar belakang secara bebas, dalam konteks Indonesia, tanpa memfokuskan pada salah satu pilihan aspek latar belakang.

\section{Bahan dan Metode}

Penelitian ini menggunakan paradigma post-positivism dengan menetapkan langkah penelitian berdasarkan pengalaman dan referensi tanpa terlebih dahulu melihat sifat dari objek yang diteliti (Kumar, 2005). Metode yang digunakan dalam penelitian ini adalah mixed-method dengan memberikan pertanyaan terbuka pada kuesioner pilot dan hasil analisis pilot tersebut menjadi kerangka kuesioner untuk penelitian tahap selanjutnya (Creswell, 2002). Kuesioner dilakukan dalam dua tahap untuk dapat melihat gambaran umum preferensi secara lebih luas. Kuesioner terbuka dilakukan untuk mendapatkan sebanyak-banyaknya aspek preferensi tanpa adanya interfensi ide dari peneliti. Sementara, kuesioner tahap dua dilakukan dalam bentuk perankingan dan dilakukan dalam rangka mencari faktor kunci dari preferensi-preferensi tersebut. Penelitian ini bersifat eksplanatori dengan mencoba mencari penjelasan lebih lanjut dari hubungan antara preferensi dengan tipe hunian di kalangan mahasiswa (Kumar, 2005). Penelitian ini menggunakan pendekatan grounded theory untuk memperoleh sebuah hasil interpretasi yang berasal dari pandangan responden (Creswell, 2002). 


\subsection{Metode Pengumpulan Data}

Pengumpulan data dilakukan melalui penyebaran kuesioner daring. Kuesioner disebarkan dalam dua tahap. Setiap kuesioner berisi dua pertanyaan pokok mengenai tipe hunian saat ini dan preferensi hunian. Penyebaran kuesioner pilot dilakukan untuk mengumpulkan sebanyak mungkin aspek alasan responden terhadap preferensi tipe hunian yang dipilih. Sasaran populasi di kedua tahap adalah mahasiswa pada segala jenjang. Pengumpulan data untuk masing-masing kuesioner menggunakan metode snowball-non-random-sampling.

Kuesioner pilot disebarkan pada tanggal 27 Agustus hingga 1 September 2017 dan berhasil mengumpulkan 208 responden. Berdasarkan jenis kelamin, terdapat 75 (36\%) responden laki-laki dan 133 (64\%) responden perempuan. Berdasarkan jenjang pendidikan, terdapat $182(87,50 \%)$ responden mahasiswa S1, $14(6,73 \%)$ responden mahasiswa S2, $1(0,48 \%)$ responden mahasiswa S3, 10 (4,81\%) responden mahasiswa D1/D2/D3, dan $1(0,48 \%)$ responden yang menjalani pendidikan profesi. Berdasarkan asal daerah, terdapat $108(51,92 \%)$ responden asal Jabodetabek, 29 (13,94\%) responden asal Jawa Barat selain Bodetabek, 25 (12,02\%) responden asal Yogyakarta dan Jawa Tengah, $21(10,1 \%)$ responden asal Sumatera, 16 (7,69\%) responden asal Jawa Timur, Bali, dan Nusa Tenggara, 6 (2,88\%) responden asal Sulawesi, dan 3 (1,44\%) responden asal Kalimantan. Berdasarkan asal kampus, terdapat $103(49,52 \%)$ responden di Jawa Barat selain Bodetabek, 61 (29,33\%) responden di Jabodetabek, 23 (11,06\%) responden di Yogyakarta dan Jawa Tengah, 8 (3,85\%) responden di Sumatera, 7 (3,37\%) responden di Sulawesi, dan 6 (2,88\%) responden di Jawa Timur, Bali dan Nusa Tenggara. Berdasarkan tipe hunian saat ini, terdapat 98 (47\%) responden penghuni indekos, 57 $(28 \%)$ responden penghuni rumah orang tua, 27 (13\%) responden penghuni kontrakan, $10(5 \%)$ responden penghuni asrama, 7 (3\%) responden penghuni rumah kerabat, 7 (3\%) responden penghuni rumah beli, dan $2(1 \%)$ responden penghuni apartemen.

Analisis data teks dilakukan terhadap jawaban-jawaban dari pertanyaan terbuka mengenai alasan preferensi tipe hunian saat ini. Analisis data teks dilakukan dalam bentuk open-coding. Melalui proses open-coding dari kuesioner pilot, diperoleh sebanyak 70 kata kunci yang kemudian dikonfirmasi kembali kepada responden melalui kuesioner tahap dua. Proses axial-coding untuk mengelompokkan kata kunci-kata kunci tersebut ke dalam kategori secara manual berdasarkan interpretasi peneliti. Diperoleh 18 kategori yaitu aksesibilitas, attachment dengan orang sekitar, fasilitas, keamanan, kebebasan, kebergantungan pada pihak tertentu, kebersihan, kedekatan dengan orang tertentu, kemandirian, kepemilikan, ketenangan, pembiayaan, pemeliharaan, penghawaan dan/atau pencahayaan alami, privasi, rekomendasi/permintaan pihak tertentu, suasana, dan tidak ada alasan spesifik.

Pada kuesioner tahap dua, responden diminta untuk melakukan penilaian terhadap tingkat kepentingan pada alasan-alasan yang terungkap dari kuesioner pilot menggunakan skala Likert dengan rentang 1sampai dengan 7. Kuesioner tahap dua disebarkan pada tanggal 22 Oktober hingga 31 Oktober 2017 dan berhasil mengumpulkan 102 responden. Berdasarkan jenis kelamin, terdapat 37 (36\%) responden laki-laki dan 65 (64\%) responden perempuan. Berdasarkan jenjang pendidikan, terdapat $89(87,25 \%)$ responden mahasiswa S1, 5 (4.90\%) responden mahasiswa S2, $1(0,98 \%)$ responden mahasiswa $S 3$, dan 7 (6,86\%) responden mahasiswa D1/D2/D3. Berdasarkan asal daerah, terdapat 63 (61,76\%) responden asal Jabodetabek, $11(10,78 \%)$ responden asal Jawa Barat selain Bodetabek, 10 (9,8\%) responden asal Jawa Timur, Bali, dan Nusa Tenggara, $8(7,84 \%)$ responden asal Yogyakarta dan Jawa Tengah, 8 (7,84\%) responden asal Sumatera, dan 2 (1,96\%) responden asal Sulawesi. Berdasarkan asal kampus, terdapat 50 (49,02\%) responden di Jawa Barat selain 
Bodetabek, 30 (29,41\%) responden di Jabodetabek, 14 (13,73\%) responden di Yogyakarta dan Jawa Tengah, 6 (5,88\%) responden di Jawa Timur, Bali dan Nusa Tenggara dan $2(1,96 \%)$ responden di Sulawesi. Berdasarkan tipe hunian saat ini, terdapat $46(45 \%)$ responden penghuni indekos, 26 (25\%) responden penghuni rumah orang tua, $11(11 \%)$ responden penghuni kontrakan, 11 (11\%) responden penghuni asrama, $5(5 \%)$ responden penghuni rumah kerabat, 2 (2\%) responden penghuni rumah beli, dan $1(1 \%)$ responden penghuni apartemen.

\subsection{Metode Analisis Data}

Analisis data pada penelitian ini dilakukan secara kuantitatif dalam bentuk analisis faktor dan ANOVA (analysis of variance). Analisis faktor dilakukan untuk mencari variabel laten dengan melihat kecenderungan kesamaan nilai yang diberikan responden. ANOVA dilakukan dua kali terhadap variabel laten. ANOVA yang pertama dilakukan untuk melihat signifikansi hubungan antara alasan dengan preferensi tipe hunian saat ini. Variabel laten dengan nilai signifikansi yang tinggi tersebut berikutnya akan disimpulkan sebagai faktor kunci yang menjadi pembeda antara preferensi tipe-tipe hunian. ANOVA yang kedua dilakukan untuk melihat perbandingan penilaian tingkat kepentingan masing-masing faktor kunci pada masing-masing preferensi tipe hunian. Secara lebih jelas, alur penelitian dapat dilihat dalam diagram berikut.

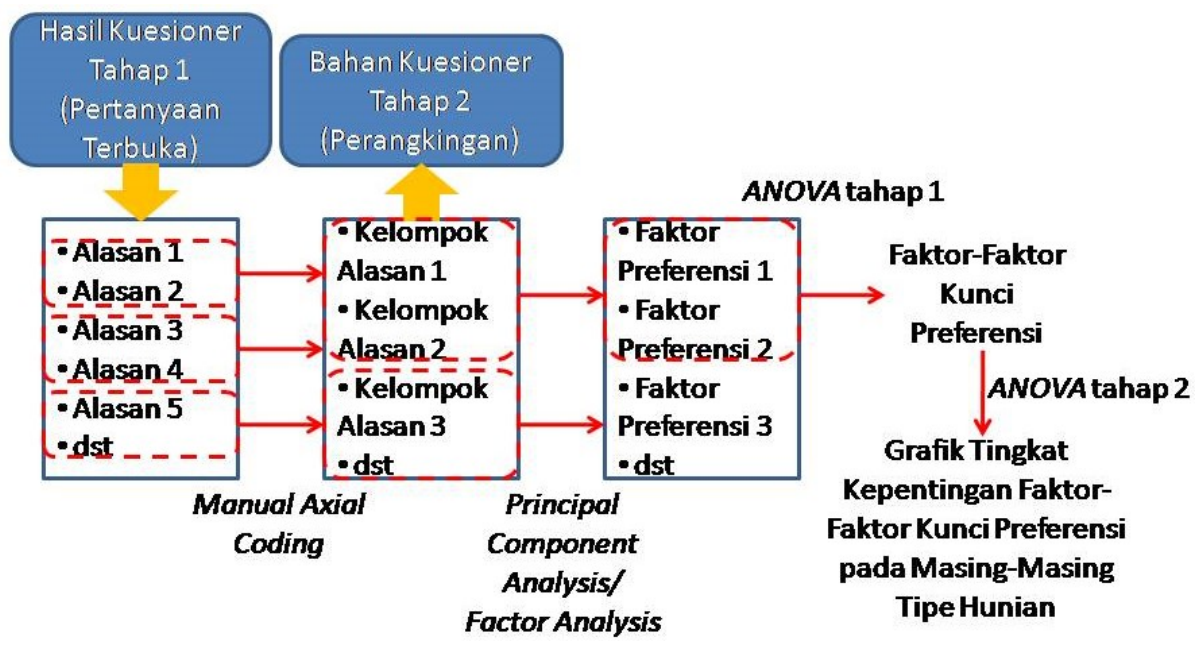

Gambar 1. Diagram alur penelitian.

(Sumber: Analisis penulis, 2018)

\section{Hasil dan Diskusi}

Dilakukan analisis faktor terhadap 70 kata kunci untuk mendapatkan variabel laten. Proses principal components/factor analysis (PCA) dilakukan memakai scree plot dengan melihat titik perubahan kecenderungan kemiringan grafik menjadi landai. Jumlah faktor ditetapkan di angka 14 pada nilai eigenvalue 1.3368 dan presentasi kumulatif $67.030 \%$. Hasil dari analisis faktor dapat dilihat pada Tabel 1 (variabel laten dengan nilai faktor kurang dari 0.46 tidak ditampilkan). 
Tabel 1. Hasil Analisis Pemfaktoran Kata Kunci ke dalam Variabel Laten

\begin{tabular}{|c|c|c|c|c|c|c|c|c|c|c|c|c|c|c|}
\hline & $\mathrm{F} 1$ & $\mathrm{~F} 2$ & F3 & $\mathrm{F} 4$ & F5 & $\mathrm{F} 6$ & $\mathrm{~F} 7$ & $\mathrm{~F} 8$ & F9 & F10 & $\mathrm{F} 11$ & $\mathrm{~F} 12$ & $\mathrm{~F} 13$ & $\mathrm{~F} 14$ \\
\hline Mengatur Urusan Sendiri & 0.70 & 0.06 & 0.08 & 0.03 & 0.06 & 0.09 & 0.00 & -0.01 & 0.14 & -0.02 & 0.33 & 0.03 & -0.04 & -0.01 \\
\hline Kekhususan Gender & 0.63 & -0.14 & -0.03 & 0.03 & -0.10 & 0.05 & -0.12 & -0.09 & 0.03 & 0.20 & -0.02 & 0.13 & 0.17 & -0.13 \\
\hline Akses Kampus & 0.62 & 0.02 & 0.14 & 0.16 & 0.03 & -0.04 & 0.01 & 0.00 & 0.01 & -0.04 & -0.03 & 0.00 & 0.10 & -0.10 \\
\hline Pembayaran Tahunan & 0.58 & 0.00 & -0.02 & 0.12 & 0.12 & 0.07 & 0.15 & 0.04 & 0.11 & 0.02 & -0.07 & 0.32 & 0.05 & -0.14 \\
\hline Suasana Baru & 0.57 & 0.13 & 0.15 & -0.09 & 0.07 & 0.26 & 0.10 & 0.00 & 0.26 & 0.13 & 0.03 & 0.13 & 0.17 & 0.13 \\
\hline Jarang Terjadi Kemacetan & 0.51 & 0.25 & 0.27 & 0.06 & 0.03 & 0.00 & 0.03 & 0.18 & 0.14 & -0.31 & 0.20 & -0.12 & 0.07 & 0.21 \\
\hline Kepemilikan Hunian & -0.49 & 0.07 & 0.11 & 0.16 & 0.21 & 0.20 & 0.05 & 0.21 & -0.08 & -0.01 & 0.14 & 0.27 & -0.43 & 0.06 \\
\hline Kedekatan Kerabat & -0.56 & 0.08 & 0.08 & 0.32 & 0.10 & -0.23 & 0.15 & 0.14 & 0.06 & 0.02 & 0.02 & 0.16 & 0.11 & 0.06 \\
\hline Kedekatan Pemenuh Kebutuhan & -0.62 & 0.31 & -0.02 & 0.06 & 0.26 & 0.08 & 0.08 & 0.07 & 0.00 & -0.07 & -0.09 & 0.23 & -0.09 & -0.17 \\
\hline Kedekatan Orang Tua & -0.79 & 0.06 & 0.14 & 0.09 & 0.07 & -0.13 & 0.04 & 0.21 & -0.15 & -0.14 & -0.07 & 0.11 & 0.06 & 0.01 \\
\hline Kepercayaan Penghuni & -0.10 & 0.69 & 0.18 & -0.10 & 0.30 & 0.14 & 0.06 & 0.08 & -0.08 & 0.07 & 0.09 & 0.09 & -0.20 & -0.02 \\
\hline Dapur & -0.17 & 0.57 & -0.01 & 0.19 & 0.19 & 0.14 & -0.07 & -0.03 & -0.01 & 0.08 & -0.13 & -0.10 & 0.13 & 0.19 \\
\hline Suasana Homey & -0.23 & 0.55 & 0.33 & 0.02 & 0.22 & 0.20 & -0.05 & -0.02 & 0.07 & 0.19 & -0.02 & -0.05 & -0.17 & -0.02 \\
\hline Akses ATM & 0.06 & 0.53 & 0.04 & 0.44 & 0.00 & -0.05 & 0.21 & -0.06 & 0.09 & -0.07 & 0.08 & -0.03 & 0.20 & 0.05 \\
\hline Kebersihan Hunian & -0.13 & 0.53 & 0.29 & 0.17 & 0.04 & 0.18 & -0.06 & -0.05 & -0.17 & 0.18 & 0.00 & 0.10 & 0.07 & 0.24 \\
\hline Keamanan Lingkungan & 0.03 & 0.51 & 0.27 & 0.03 & 0.13 & 0.05 & 0.07 & 0.29 & -0.17 & 0.12 & 0.06 & 0.00 & -0.02 & 0.17 \\
\hline Kesesuaian Ukuran & 0.13 & 0.49 & 0.22 & 0.26 & 0.00 & 0.38 & 0.00 & 0.07 & 0.02 & 0.10 & 0.12 & -0.22 & -0.06 & 0.04 \\
\hline Akses Perbelanjaan & -0.07 & 0.49 & 0.12 & 0.32 & 0.05 & -0.01 & -0.07 & 0.10 & 0.07 & -0.02 & 0.02 & -0.17 & 0.00 & -0.14 \\
\hline Kondusifitas Bekerja & 0.11 & 0.49 & 0.19 & 0.07 & -0.09 & 0.29 & 0.13 & 0.09 & 0.06 & 0.14 & 0.17 & 0.05 & 0.05 & 0.16 \\
\hline Kebersihan Lingkungan & 0.02 & 0.47 & 0.39 & 0.15 & 0.05 & 0.11 & -0.06 & -0.01 & 0.00 & 0.42 & 0.00 & 0.05 & -0.05 & 0.21 \\
\hline Sirkulasi Udara & -0.02 & 0.17 & 0.84 & 0.02 & 0.09 & 0.10 & 0.05 & 0.08 & 0.00 & 0.17 & -0.05 & 0.10 & -0.01 & -0.07 \\
\hline Cahaya Matahari & 0.01 & 0.14 & 0.82 & 0.10 & 0.11 & -0.12 & 0.05 & 0.00 & 0.02 & -0.17 & 0.14 & -0.02 & 0.06 & 0.22 \\
\hline Suhu/Kelembaban Udara & 0.00 & 0.25 & 0.77 & -0.03 & -0.01 & 0.29 & -0.04 & 0.11 & -0.02 & 0.12 & 0.08 & 0.10 & 0.13 & -0.11 \\
\hline Udara Pagi & 0.00 & 0.20 & 0.77 & 0.04 & 0.10 & 0.04 & -0.02 & 0.00 & -0.02 & 0.10 & 0.08 & 0.00 & -0.07 & 0.10 \\
\hline Akses Kuliner & 0.01 & 0.26 & 0.08 & 0.78 & 0.00 & 0.11 & 0.14 & 0.04 & -0.12 & 0.16 & -0.20 & 0.08 & -0.07 & 0.10 \\
\hline Akses Fotocopy/Print & 0.02 & 0.02 & 0.06 & 0.68 & -0.08 & 0.14 & 0.00 & -0.01 & 0.01 & -0.15 & -0.12 & 0.04 & 0.10 & -0.04 \\
\hline Akses Transportasi & -0.18 & 0.13 & -0.05 & 0.58 & 0.02 & 0.00 & 0.01 & -0.04 & -0.02 & 0.06 & 0.33 & -0.21 & 0.01 & -0.11 \\
\hline Akses Jalan Raya & 0.01 & 0.17 & 0.02 & 0.50 & 0.01 & 0.01 & 0.10 & 0.23 & 0.09 & 0.02 & 0.26 & -0.17 & 0.06 & -0.06 \\
\hline Kemudahan Bersosialisasi & -0.16 & 0.18 & 0.18 & -0.01 & 0.93 & 0.03 & 0.04 & 0.08 & -0.04 & 0.04 & 0.01 & 0.01 & 0.07 & 0.13 \\
\hline Kekeluargaan Penghuni & -0.34 & 0.42 & 0.15 & 0.02 & 0.68 & 0.11 & 0.02 & 0.04 & -0.03 & -0.05 & -0.17 & 0.09 & 0.00 & -0.10 \\
\hline Kenalan Baru & 0.40 & 0.20 & -0.02 & -0.01 & 0.60 & 0.17 & -0.08 & 0.12 & 0.06 & 0.06 & 0.07 & 0.06 & 0.21 & -0.06 \\
\hline Harga Sesuai Fasilitas & 0.04 & 0.21 & 0.05 & 0.04 & 0.00 & 0.91 & 0.01 & 0.09 & 0.13 & 0.07 & 0.20 & 0.01 & 0.09 & 0.06 \\
\hline Keterjangkauan Harga & 0.09 & 0.13 & 0.11 & 0.01 & 0.18 & 0.70 & 0.10 & -0.06 & 0.03 & 0.07 & -0.06 & 0.06 & -0.08 & 0.08 \\
\hline Paket Harga Lengkap & 0.23 & 0.28 & 0.01 & 0.10 & 0.06 & 0.55 & -0.04 & 0.11 & -0.02 & 0.36 & 0.01 & -0.22 & 0.11 & 0.02 \\
\hline Kebebasan & 0.01 & 0.11 & 0.01 & 0.14 & 0.03 & 0.09 & 0.89 & 0.05 & 0.01 & -0.03 & 0.14 & -0.03 & -0.01 & -0.01 \\
\hline Ketiadaan Aturan & -0.05 & 0.04 & 0.07 & 0.13 & 0.03 & 0.06 & 0.87 & 0.10 & -0.01 & 0.01 & 0.09 & -0.05 & -0.10 & -0.01 \\
\hline Kemungkinan Investasi & -0.41 & 0.15 & 0.12 & 0.15 & 0.08 & 0.11 & 0.08 & 0.74 & -0.11 & 0.01 & 0.01 & 0.17 & -0.05 & 0.24 \\
\hline Kemungkinan Pewarisan & -0.44 & 0.11 & 0.08 & 0.04 & 0.08 & 0.14 & 0.15 & 0.72 & -0.04 & -0.02 & -0.03 & 0.12 & -0.06 & 0.25 \\
\hline Rekomendasi & 0.27 & 0.00 & -0.07 & 0.03 & 0.00 & 0.10 & 0.06 & -0.04 & 0.93 & 0.12 & 0.07 & 0.10 & 0.09 & 0.01 \\
\hline Referensi & 0.28 & -0.14 & 0.03 & 0.02 & -0.01 & 0.09 & -0.01 & -0.06 & 0.78 & 0.09 & 0.14 & 0.14 & -0.07 & -0.07 \\
\hline Kemudahan Bentuk Pemeliharaan & 0.04 & 0.40 & 0.22 & -0.01 & 0.12 & 0.18 & 0.08 & 0.04 & 0.06 & 0.54 & 0.10 & -0.02 & -0.15 & 0.06 \\
\hline Fasilitas Pembersihan & 0.08 & 0.16 & -0.04 & -0.18 & -0.02 & 0.11 & -0.05 & 0.13 & 0.13 & 0.46 & 0.23 & 0.00 & 0.13 & -0.02 \\
\hline Ukuran Kewajiban Pembersihan & 0.14 & 0.08 & 0.20 & 0.07 & -0.05 & 0.05 & -0.06 & -0.21 & 0.07 & 0.46 & 0.05 & 0.23 & 0.11 & -0.06 \\
\hline Kepemilikan Barang & 0.05 & -0.05 & 0.16 & -0.11 & 0.00 & 0.02 & 0.31 & 0.00 & 0.17 & 0.13 & 0.49 & 0.10 & 0.04 & 0.11 \\
\hline Privasi & 0.26 & -0.07 & 0.00 & -0.02 & -0.31 & 0.04 & 0.15 & 0.00 & 0.21 & 0.17 & 0.46 & 0.14 & 0.13 & 0.27 \\
\hline Permintaan Pihak Lain & -0.10 & -0.04 & 0.05 & -0.05 & 0.03 & -0.12 & 0.00 & 0.05 & 0.12 & 0.07 & 0.11 & 0.71 & 0.02 & 0.09 \\
\hline Kewajiban Pihak Lain & 0.05 & -0.03 & 0.02 & -0.05 & 0.08 & 0.06 & -0.05 & 0.12 & 0.05 & 0.01 & -0.04 & 0.62 & -0.01 & 0.03 \\
\hline Balkon & 0.14 & 0.06 & 0.14 & 0.09 & 0.16 & 0.18 & -0.11 & 0.14 & 0.04 & 0.03 & -0.13 & 0.01 & 0.51 & -0.08 \\
\hline Kamar Mandi Dalam & 0.15 & -0.02 & -0.06 & 0.04 & 0.02 & -0.04 & -0.19 & -0.15 & -0.11 & 0.13 & 0.10 & 0.06 & 0.48 & 0.06 \\
\hline Suasana Komplek & -0.16 & 0.16 & 0.09 & -0.05 & 0.00 & 0.06 & -0.05 & 0.19 & -0.02 & 0.00 & 0.05 & 0.04 & 0.02 & 0.60 \\
\hline
\end{tabular}


Kata kunci yang terkumpul dalam satu variabel laten yang sama ditandai oleh nilai pemfaktoran yang besar. Hal ini menunjukkan bahwa kata kunci-kata kunci tersebut memiliki kecenderungan mendapatkan tingkat penilaian yang sama dari setiap responden. Pemfaktoran yang bernilai negatif menunjukkan kecenderungan tingkat penilaian yang bertolak belakang secara berulang dari kata kunci yang bernilai positif dalam satu kelompok variabel laten yang sama. Semakin tinggi penilaian kepentingan yang diberikan responden terhadap kata kunci yang bernilai positif, maka terdapat kecenderungan penilaian yang semakin rendah terhadap kata kunci yang bernilai negatif, begitu juga sebaliknya. Sebagai contoh, kata kunci "mengatur urusan sendiri" dan "kedekatan orang tua" pada variabel laten "kemandirian", semakin tinggi penilaian kepentingan responden terhadap kata kunci pertama, maka terdapat kecenderungan penilaian yang semakin rendah terhadap kata kunci kedua dalam kaitannya terhadap alasan preferensi tipe hunian.

Berdasarkan analisis faktor tersebut, didapatkan 14 variabel laten. Variabel laten itu adalah kemandirian, suasana, kenyamanan, aksesibilitas, interaksi sosial, pembiayaan, kebebasan, kepemilikan, informasi, pemeliharaan, privasi, tuntutan, fasilitas privat, dan perumahan. Hasil ini tidak terlalu jauh jika dibandingkan dengan hasil analisis manual axial-coding pada data kuesioner pilot yang terdiri dari 18 kategori. Variabel laten yang juga muncul pada penelitian tahap sebelumnya yaitu kemandirian, suasana, aksesibilitas, pembiayaan, kebebasan, kepemilikan, pemeliharaan, privasi, dan fasilitas (Reski dan Tampubolon, 2017). Faktor kenyamanan pada penelitian sebelumnya diberi nama penghawaan dan/atau pencahayaan alami. Kategori kedekatan dan attachment dengan orang tertentu pada penelitian ini menjadi satu faktor yaitu interaksi sosial. Faktor informasi dan tuntutan pada penelitian tahap sebelumnya dijadikan satu kategori yaitu rekomendasi/permintaan dari pihak tertentu. Faktor perumahan pada penelitian tahap sebelumnya dijadikan satu dengan kategori suasana. Kategori kebergantungan dengan pihak tertentu pada penelitian ini dijadikan satu dengan faktor kemandirian. Kategori keamanan, kebersihan, dan ketenangan pada penelitian ini tergabung dalam faktor suasana.

Faktor-faktor alasan yang didapatkan dari penelitian ini juga cukup sesuai dengan beberapa faktor preferensi hunian dari beberapa referensi. Faktor-faktor tersebut adalah fasilitas (Abdassah, Anandhita, dan Sesotyaningtyas, 2013; Adrian, 2015; Andoni dan Kusuma, 2016; Khozaei, Hassan, dan Razak, 2011; Mandasari, 2015; Muchlis dan Kusuma, 2016; Putra, Widyasanti, dan Natasya, 2013; Rachman dan Kusuma, 2016; Sakina dan Kusuma, 2015), kenyamanan/lingkungan alami (Abdassah, Anandhita, dan Sesotyaningtyas, 2013; Andoni dan Kusuma, 2016; Khozaei, Hassan, dan Razak, 2011; Mandasari, 2015; Muchlis dan Kusuma, 2016; Putra, Widyasanti, dan Natasya, 2013; Sakina dan Kusuma, 2015), suasana, interaksi (Abdassah, Anandhita, dan Sesotyaningtyas, 2013; Andoni dan Kusuma, 2016; Khozaei, Hassan, dan Razak, 2011; Mandasari, 2015; Muchlis dan Kusuma, 2016; Putra, Widyasanti, dan Natasya, 2013), aksesibilitas/lokasi (Adrian, 2015; Khozaei, Hassan, dan Razak, 2011; Mandasari, 2015; Sakina dan Kusuma, 2015), pembiayaan (Mandasari, 2015; Sakina dan Kusuma, 2015), dan privasi (Rachman dan Kusuma, 2016). Faktor yang muncul dalam referensi tetapi tidak muncul dalam hasil penelitian ini adalah karakter arsitektural (Abdassah, Anandhita, dan Sesotyaningtyas, 2013; Adrian 2015; Andoni dan Kusuma, 2016; Muchlis dan Kusuma, 2016; Putra, Widyasanti, dan Natasya, 2013; Rachman dan Kusuma 2016). Faktor kepemilikan/investasi (Cahyani P., Ilhamdaniah, dan Indra K.D., 2012; Catalonia, 2016; Kartamihardja, 2015) dan pemeliharaan/kepraktisan (Kartamihardja, 2015) muncul terutama dalam referensi terkait faktor preferensi apartemen. Sementara, faktor kemandirian, kebebasan, informasi, tuntutan, dan perumahan tidak ditemukan dalam referensi tetapi muncul dalam hasil penelitian ini. 
Setelah didapatkan hasil analisis faktor, ANOVA dilakukan terhadap variabelvariabel laten untuk melihat perbedaan antara variabel laten tingkat kepentingan terhadap preferensi terhadap tipe hunian. Dari 14 variabel laten, terdapat 4 variabel yang signifikan terdapat perbedaan penilaian tingkat kepentingan. Variabel-variabel tersebut adalah kemandirian, interaksi sosial, kebebasan, dan privasi. Hasil ANOVA dari keempat variabel tersebut dapat dilihat pada Gambar 2, 3, 4, dan 5.

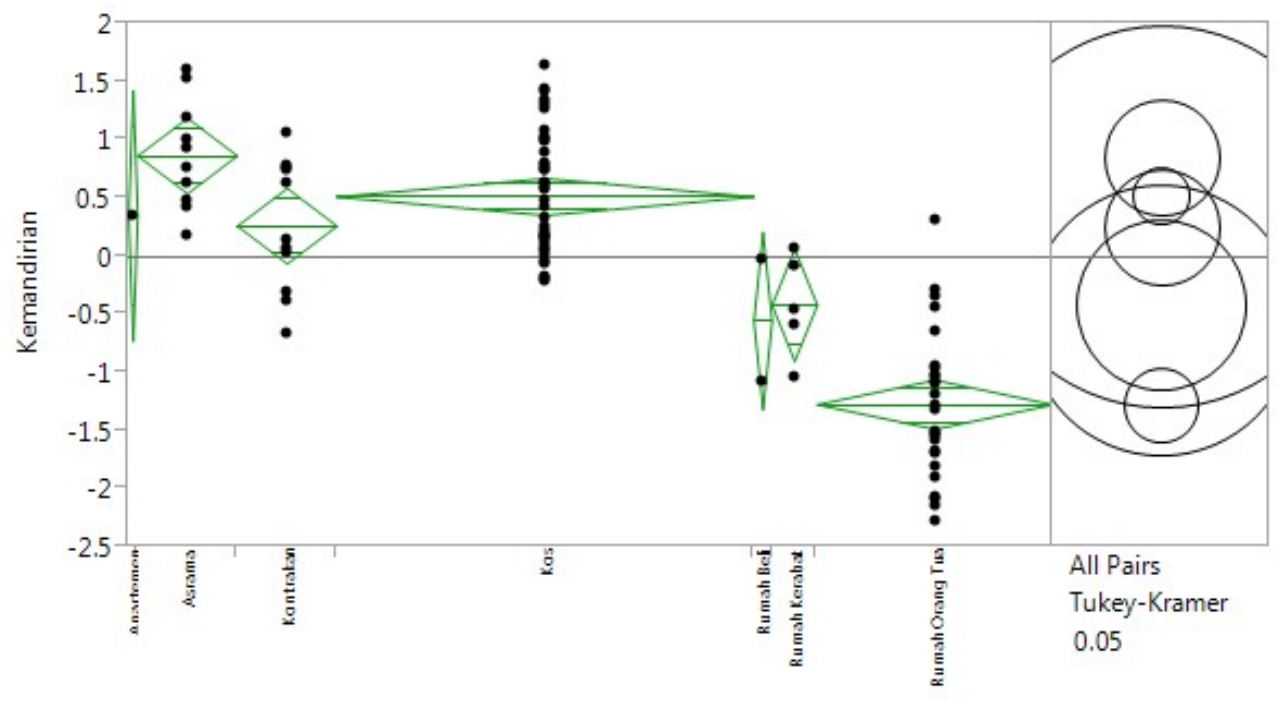

Tipe Hunian yang Dihuni Saat Ini

Gambar 2. Diagram ANOVA antara preferensi tipe hunian dan faktor kemandirian dengan nilai $\mathrm{p}<0.0001$ yang menandakan hasil yang sangat signifikan.

(Sumber: Analisis penulis, 2018)

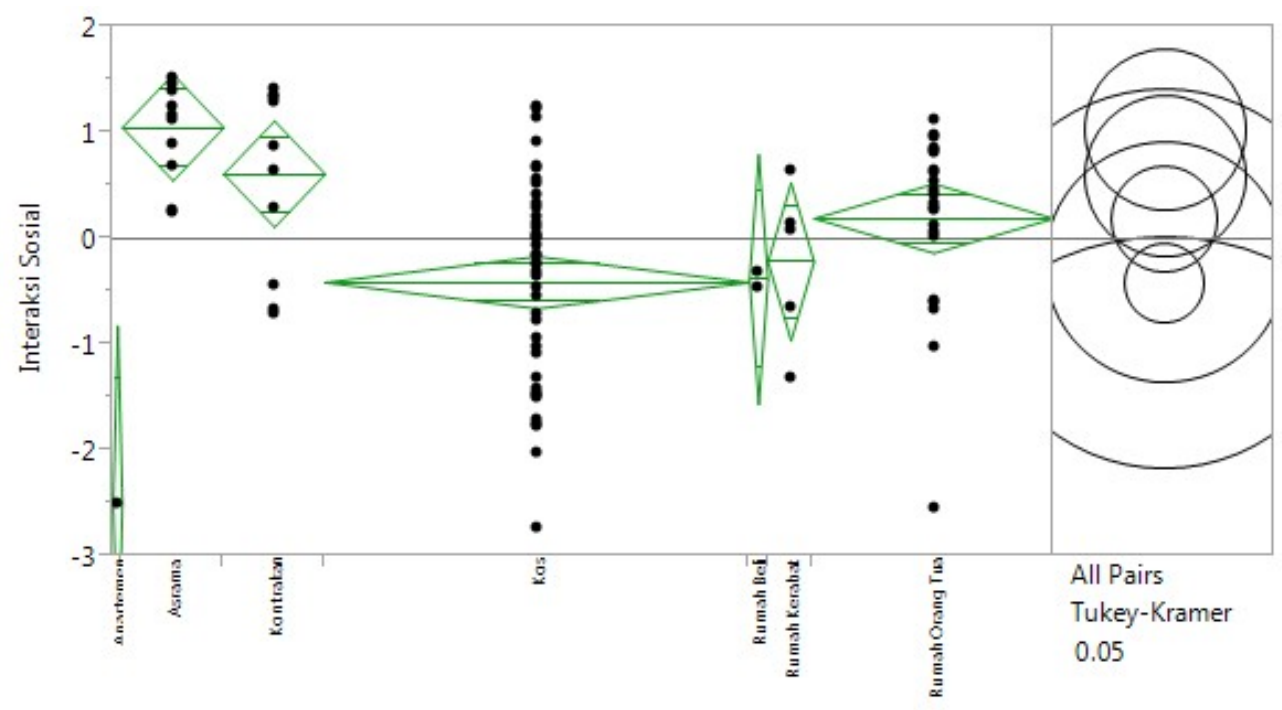

Tipe Hunian yang Dihuni Saat Ini

Gambar 3. Diagram ANOVA antara preferensi tipe hunian dan faktor interaksi sosial dengan nilai $\mathrm{p}<0.0001$ yang menandakan hasil yang sangat signifikan.

(Sumber: Analisis penulis, 2018) 


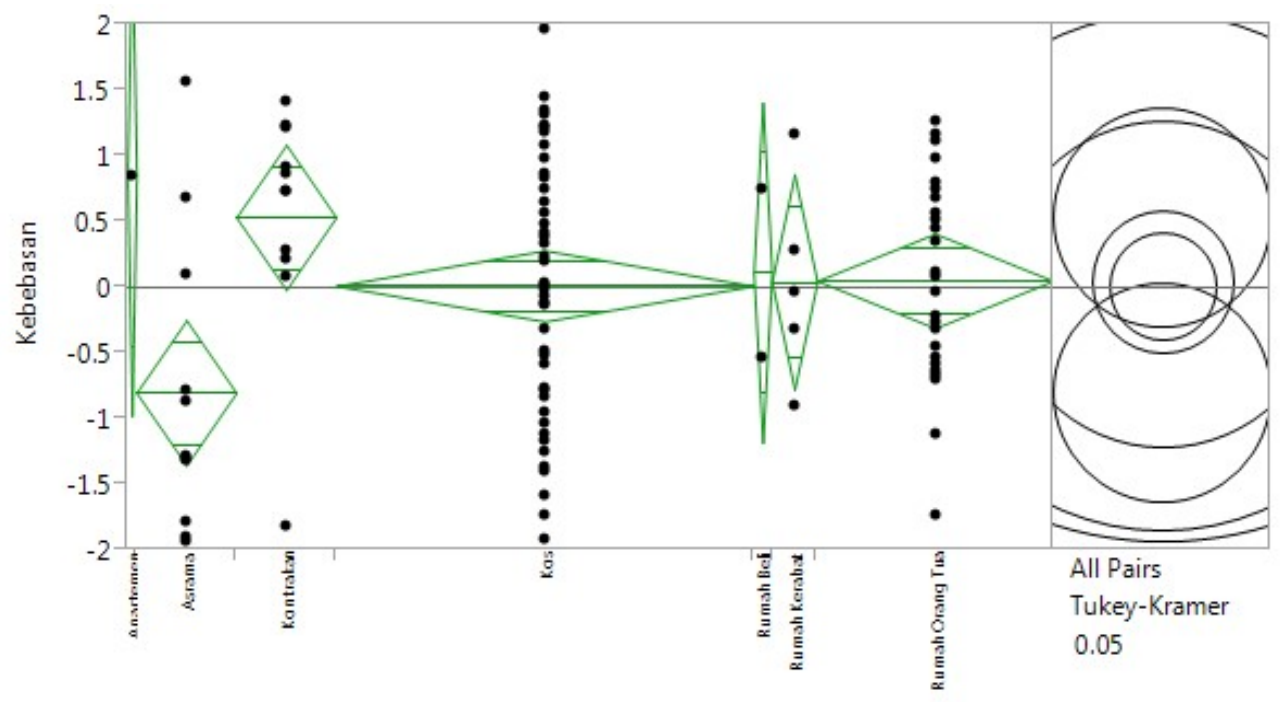

Tipe Hunian yang Dihuni Saat Ini

Gambar 4. Diagram ANOVA antara preferensi tipe hunian dan faktor kebebasan dengan nilai $\mathrm{p}<0.0532$ yang menandakan hasil yang sangat signifikan.

(Sumber: Analisis penulis, 2018)

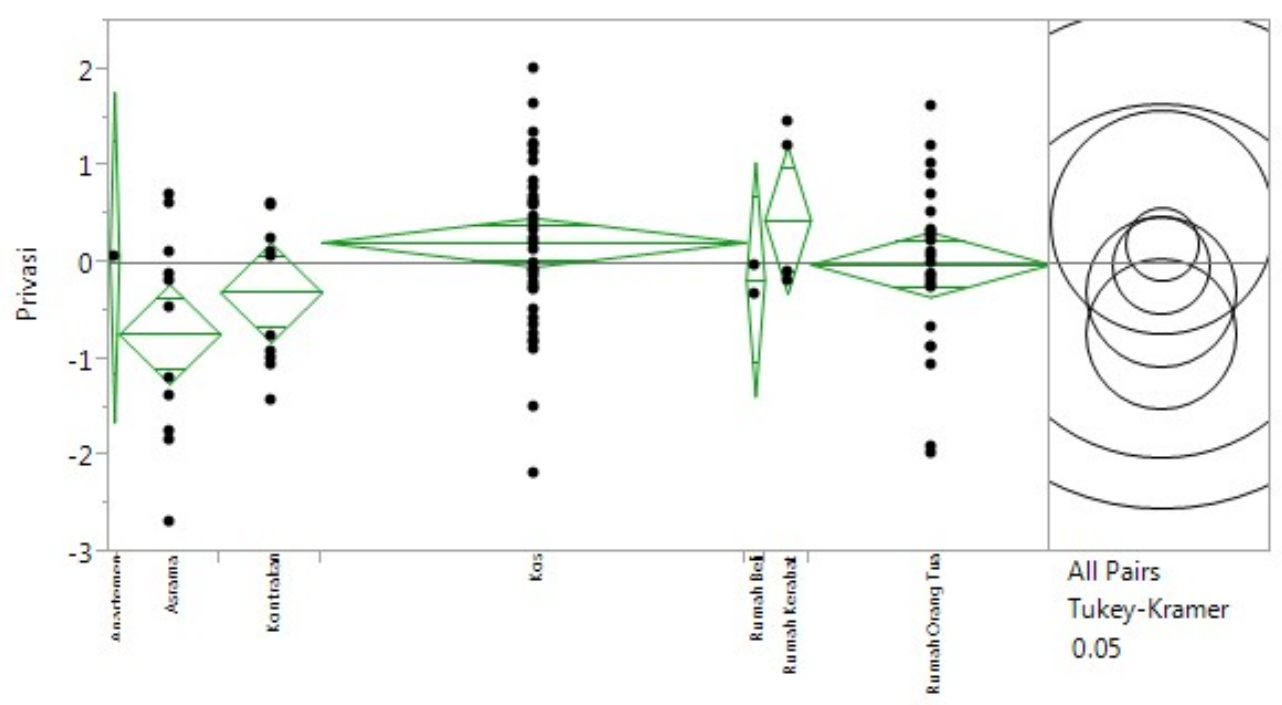

Tipe Hunian yang Dihuni Saat Ini

Gambar 5. Diagram ANOVA antara preferensi tipe hunian dan faktor privasi dengan nilai $\mathrm{p}<0.0423$ yang menandakan hasil yang sangat signifikan.

(Sumber: Analisis penulis, 2018)

Jika diperhatikan, keempat variabel laten yang menjadi faktor utama dalam perbandingan preferensi tipe hunian tersebut memiliki kemiripan. Keempat variabel laten tersebut dapat dikategorikan ke dalam sebuah kategori besar terkait hubungan dengan orang lain. Hal ini dapat diinterpretasikan dengan melihat betapa seringnya faktor hubungan dengan orang lain ini muncul dalam beberapa referensi penelitian. Faktor ini muncul dalam penilaian keidealan hunian oleh Abdassah, Anandhita, dan Sesotyaningtyas (2013), Andoni dan Kusuma (2016), Muchlis dan Kusuma (2016), serta 
Putra, Widyasanti, dan Natasya, (2013). Bahkan, Rachman dan Kusuma (2016) juga menyebutkan privasi sebagai salah satu faktor penentu kebetahan dalam kamar.

Hal ini kemungkinan disebabkan oleh fungsi hunian sebagai tempat beristirahat dan meninggalkan dunia luar untuk dapat menikmati kehidupan pribadi (Marc dalam Abdassah, Anandhita, dan Sesotyaningtyas, 2013). Dalam hal itu, Sari, Kusuma, dan Tedjo (2012) juga menyebutkan bahwa ruang pribadi dapat menjadi tempat favorit untuk sarana restoratif bagi sebagian kecil orang. Sakina dan Kusuma (2014) menyebutkan bahwa salah satu fungsi hunian adalah sebagai penyedia privasi dan personalisasi. Kurniati dan Kusuma (2014) juga menyebutkan bahwa semakin dewasa seorang manusia, maka kebutuhan akan privasi juga semakin meningkat. Rapoport (dalam Triyuly dan Kusuma, 2015) menyatakan bahwa privasi merupakan salah satu kebutuhan dasar penghuni hunian. Terakhir, Lisa (2016) menyatakan bahwa privasi merupakan hal yang universal dan memiliki kontribusi terhadap kebutuhan manusia lainnya seperti rasa aman, afiliasi, dan penghargaan.

Dalam ranah psikologi, kemunculan empat variabel laten tersebut dapat dikaitkan dengan teori dasar kepribadian manusia. Teori dasar kepribadian manusia yang banyak dipakai adalah mengenai extraversion dan introversion dari Carl Jung (dalam Delima P., 2016) serta ambiversion dari Cohen (dalam Delima P., 2016). Secara garis besar, dapat dijelaskan bahwa manusia dengan kepribadian extraversion menerima energi dari berhubungan dengan orang lain. Introversion lebih banyak menerima energi dari dirinya sendiri dengan cara menyendiri. Ambiversion merupakan kepribadian pertengahan atau campuran dari dua kepribadian sebelumnya. Dari penjelasan ini, dapat diinterpretasikan bahwa manusia dengan kepribadian dasar yang berbeda akan memiliki penilaian tingkat kepentingan yang berbeda pula terhadap faktor-faktor yang berkaitan dengan hubungan dengan orang lain. Karena tipe kepribadian ini merupakan kepribadian dasar manusia, menjadi masuk akal apabila faktor hubungan dengan orang lain menjadi faktor kunci yang dipertimbangkan mahasiswa dalam menentukan preferensi tipe hunian.

Setelah mendapatkan empat faktor kunci preferensi tipe hunian, ANOVA dilakukan kembali terhadap empat faktor tersebut secara bersamaan untuk dapat melihat perbandingan penilaian tingkat kepentingan setiap faktor kunci pada setiap tipe hunian. Hasil ANOVA dapat dilihat pada Gambar 5.

Dari hasil ANOVA dapat disimpulkan bahwa responden yang memilih tipe hunian apartemen cenderung merasa membutuhkan kebebasan, kemandirian, dan privasi, tetapi kurang membutuhkan interaksi sosial. Responden yang memilih tipe hunian asrama cenderung membutuhkan interaksi sosial dan kemandirian, tetapi kurang membutuhkan kebebasan dan privasi. Responden yang memilih tipe hunian kontrakan cenderung membutuhkan interaksi sosial, kebebasan, dan kemandirian, tetapi kurang membutuhkan privasi. Responden yang memilih tipe hunian indekos cenderung membutuhkan kemandirian, privasi, dan kebebasan, tetapi kurang membutuhkan interaksi sosial. Responden yang memilih tipe hunian rumah beli cenderung membutuhkan kebebasan, tetapi kurang membutuhkan kemandirian, interaksi sosial, dan privasi. Responden yang memilih tipe hunian rumah kerabat cenderung membutuhkan privasi dan kebebasan, tetapi tidak membutuhkan kemandirian, dan interaksi sosial. Responden yang memilih tipe hunian rumah orang tua cenderung membutuhkan interaksi sosial, kebebasan, dan privasi, tetapi kurang membutuhkan kemandirian.

Faktor interaksi sosial dan kemandirian dengan penilaian tertinggi muncul pada tipe hunian asrama. Faktor kebebasan dengan penilaian tertinggi muncul pada tipe hunian apartemen. Faktor privasi dengan penilaian tertinggi muncul pada tipe hunian rumah kerabat. Faktor interaksi sosial dengan penilaian terendah muncul pada tipe hunian apartemen. Faktor kemandirian dengan penilaian terendah muncul pada tipe 
hunian rumah orang tua. Faktor kebebasan dan privasi dengan penilaian terendah muncul pada tipe hunian asrama.

Hasil temuan ini cenderung mirip dengan penelitian penulis sebelumnya dengan metode analisis korespondensi. Pada penelitian sebelumnya, penulis menemukan adanya kecenderungan alasan privasi pada pemilih tipe hunian indekos. Terdapat juga kecenderungan alasan kemandirian, kebebasan, dan hubungan sosial pada pemilih tipe hunian kontrakan, serta kecenderungan alasan kebergantungan pada pemilih tipe hunian rumah orang tua (Reski dan Tampubolon, 2017).

Hal tersebut dapat diinterpretasikan dari sifat apartemen dan indekos yang merupakan bangunan hunian vertikal. Ananto (2015) menyatakan bahwa teritorialitas sebagai akibat dari interaksi sosial yang merupakan perilaku dasar budaya permukiman horizontal tidak lagi muncul pada permukiman vertikal. Hal ini disebabkan tergantikannya keberadaan jalan muka rumah sebagai jalur sirkulasi sekaligus tempat berinteraksi dengan koridor sempit yang hanya bisa dijadikan sebagai jalur sirkulasi saja. Catalonia (2016) menyatakan bahwa, saat ini, belum banyak desain apartemen, khususnya di Indonesia, yang dianggap berhasil meningkatkan kualitas hubungan sosial penghuninya. Selain itu, dalam penelitian Sakina dan Kusuma (2016) juga didapatkan bahwa tipe hunian sewa rumah, yang dalam penelitian ini didefinisikan sebagai kontrakan, memiliki potensi terbesar menciptakan hubungan sosial. Sementara, tipe hunian sewa indekos memiliki potensi terendah. Sehingga, menjadi logis apabila mahasiswa yang lebih mementingkan privasi cenderung memilih apartemen dan indekos sebagai preferensi hunian. Selain itu, adanya besaran unit yang dimiliki atau disewakan pada apartemen dan indekos berupa satu paket kamar lengkap, minimal berupa kamar tidur dan kamar mandi pribadi, semakin menjadikan kedua tipe hunian ini menjadi pilihan utama mahasiswa yang mengedepankan privasi. Hal ini sebagaimana yang disebutkan oleh Khozaei, Hassan, Al Kodmany, dan Aarab (2014) bahwa para mahasiswa yang menyukai privasi ini cenderung memiliki ketertarikan tinggal pada ruang yang memiliki batasan area yang jelas untuk masing-masing penghuni. Oppewal, Poria, Ravenscroft, dan Speller (2005) juga menyebutkan bahwa para mahasiswa ini memiliki sensitivitas tinggi terhadap keharusan berbagi fasilitas toilet dan kamar mandi dengan orang lain. Adapun asrama, meskipun umumnya merupakan bangunan hunian vertikal, keberadaan program dan peraturan-peraturan yang mengikat menyebabkan tingginya tingkat interaksi dan kemandirian penghuni. Selain itu, sebagian besar asrama juga biasanya mengharuskan adanya pembagian kamar antara dua penghuni atau lebih sehingga semakin meningkatkan interaksi sosial. 


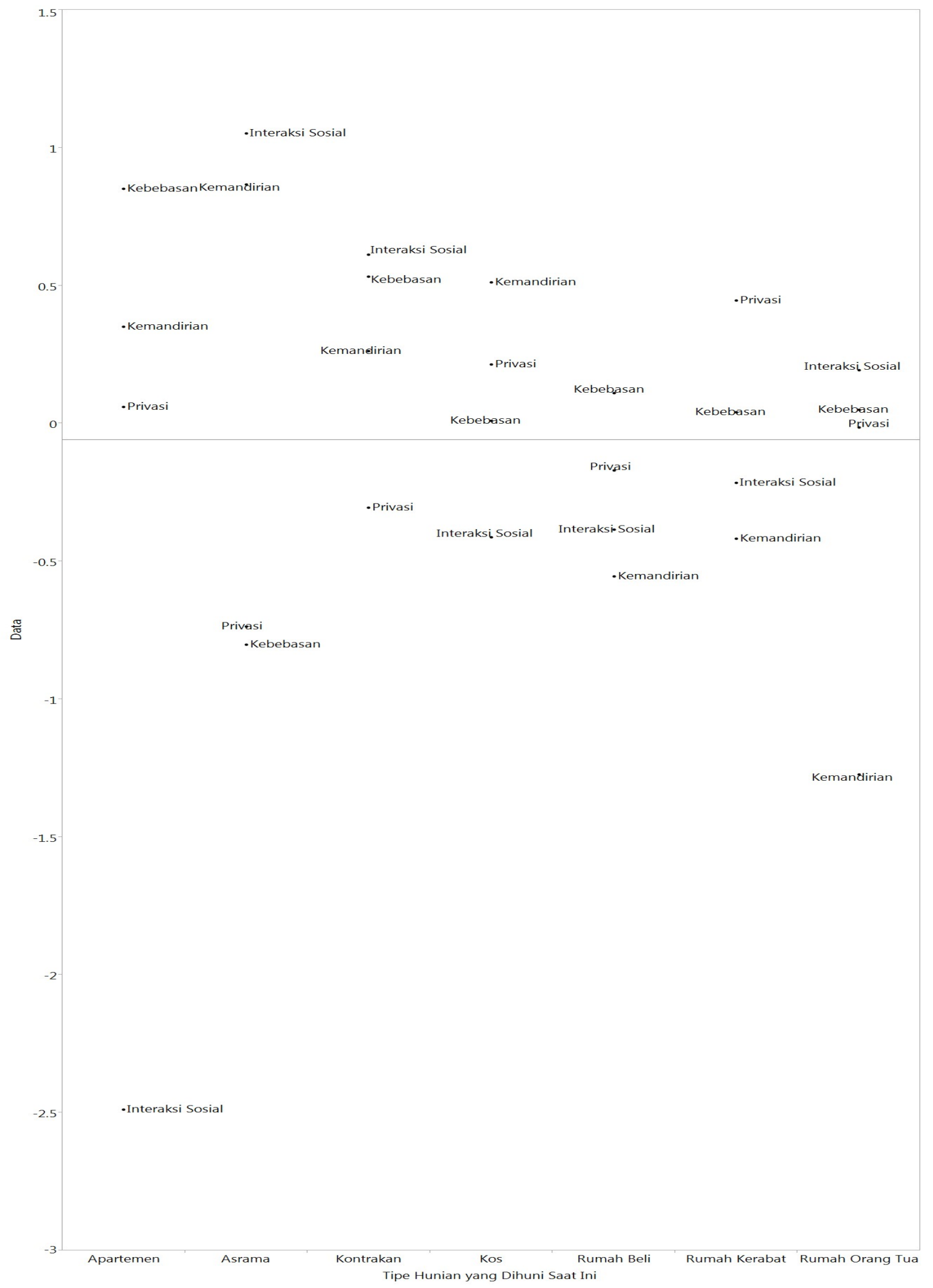

Gambar 5. Diagram ANOVA empat faktor kunci alasan preferensi tipe hunian terhadap tipe hunian yang dihuni saat ini

(Sumber: Analisis penulis, 2018) 


\section{Simpulan}

Berdasarkan analisis faktor, didapatkan 14 variabel laten alasan preferensi tipe hunian di kalangan mahasiswa. Variabel laten itu adalah kemandirian, suasana, kenyamanan, aksesibilitas, interaksi sosial, pembiayaan, kebebasan, kepemilikan, informasi, pemeliharaan, privasi, tuntutan, fasilitas privat, dan perumahan.

Berdasarkan hasil ANOVA antara tipe hunian dengan variabel laten penilaian tingkat kepentingan, didapatkan 4 dari 14 variabel laten yang dinilai signifikan berbeda. Variabel-variabel tersebut adalah kemandirian, interaksi sosial, kebebasan, dan privasi. Variabel-variabel ini merupakan faktor kunci yang dipertimbangkan mahasiswa dalam menentukan preferensi tipe hunian.

Ditemukan bahwa faktor interaksi sosial dan kemandirian dengan penilaian tertinggi muncul pada tipe hunian asrama. Faktor kebebasan dengan penilaian tertinggi muncul pada tipe hunian apartemen. Faktor privasi dengan penilaian tertinggi muncul pada tipe hunian rumah kerabat. Sementara, faktor interaksi sosial dengan penilaian terendah muncul pada tipe hunian apartemen. Faktor kemandirian dengan penilaian terendah muncul pada tipe hunian rumah orang tua. Faktor kebebasan dan privasi dengan penilaian terendah muncul pada tipe hunian asrama.

Penelitian ini berusaha mencari dan membandingkan penilaian tingkat kepentingan faktor kunci terhadap preferensi tipe hunian di kalangan mahasiswa. Hasil dari penelitian ini diharapkan dapat digunakan sebagai bahan pertimbangan dalam perencanaan hunian mahasiswa di masa yang akan datang, dengan memperhatikan preferensi kebutuhan sasaran penghuni terkait hubungan sosial sesuai kepribadian dasar manusia.

Penelitian ini masih memiliki kekurangan, terutama dalam pengambilan data. Jumlah responden dari setiap daerah memiliki persentase yang tidak proporsional. Sehingga, hasil penelitian ini lebih representatif untuk menggambarkan responden pada daerah Pulau Jawa, khususnya responden dengan daerah asal Jabodetabek yang menjalani kuliah di daerah Jawa Barat selain Bodetabek. Selain itu, persentase yang tidak proporsional juga terjadi pada pengambilan jumlah responden berdasarkan tipe hunian. Metode random-sampling atau quota-and-purposive-non-random-sampling lebih disarankan pada penelitian sejenis atau penelitian lanjutan dari penelitian ini.

\section{Ucapan Terima Kasih}

Ucapan terima kasih penulis sampaikan kepada Bapak Dr. Eng. Hanson Endra Kusuma, ST., M.Eng selaku dosen pengampu mata kuliah Analisis Data pada program studi magister Arsitektur di Institut Teknologi Bandung atas pengajaran mengenai metode analisis data dan bimbingan dalam pengerjaan artikel ini. Ucapan terima kasih juga penulis sampaikan kepada Angela Christysonia Tampubolon ST., MT. selaku asisten mata kuliah sekaligus penulis 2 yang telah membantu penulis utama secara langsung dalam penulisan artikel ini.

\section{Daftar Pustaka}

Abdassah, R.K., Anandhita, G., dan Sesotyaningtyas, M. (2013). Rumah Impian Mahasiswa. Prosiding Temu Ilmiah IPLBI 2013, A, 29-34.

Adrian, Aria (2015). Lingkungan Rumah Ideal. Prosiding Temu Ilmiah IPLBI 2015, C, 5762.

Ananto, Sofian D. (2015). Adaptasi Teritorialitas pada Permukiman Horizontal ke dalam Permukiman Vertikal. Prosiding Temu Ilmiah IPLBI 2015, C, 1-4. 
Andoni, H. dan Kusuma, Hanson E. (2016). Preferensi Hunian yang Ideal Bagi Pekerja dan Mahasiswa pada Kelompok Umur Dewasa Awal / Early Adulthood. Prosiding Temu Ilmiah IPLBI 2016, D, 129-134.

Catalonia, R. Muhammad Amanda (2016). Studi Preferensi dalam Pemilihan Apartemen Ideal. Prosiding Temu Ilmiah IPLBI 2016, G, 131-136.

Creswell, J.W. (2002). Research Design: Qualitative, Quantitative, and Mixed Methods Approaches. California: Sage Publications, Inc.

Kartamihardja, Andrie I. (2015). Analisis Faktor-faktor Penyebab Membeli Apartemen. Prosiding Temu Ilmiah IPLBI 2015, C, 5-10.

Khozaei, F., Hassan Ahmad S., Al Kodmany, K., dan Aarab, Y. (2014). Examination of Student Housing Preferences, Their Similarities and Differences. Facilities, Vol. 32, No. 11/12, pp. 709-722.

Khozaei, F., Hassan, Ahmad S., dan Razak, Nordin A. (2011). Development and Validation of the Student Accommodation Preferences Instrument (SAPI). Journal of Building Appraisal, Vol. 6, No. 3/4, pp. 299-313.

Khozaei, F., Ramayah, T., Hassan, Ahmad S., dan Surienty, L. (2012). Sense of Attachment to Place and Fulfilled Preferences, the Mediating Role of Housing Satisfaction. Property Management, Vol. 30, No. 3, pp. 292-310.

Kumar, Ranjit (2005). Research Methodology: A Step-By-Step Guide for Beginners. California: Sage Publications, Inc.

Kurniati, F., dan Kusuma, Hanson E. (2014). Adaptasi Perilaku dan Modifikasi sebagai Proses Menciptakan Hunian Ideal Bagi Penghuni Perumahan Massal. Prosiding Temu Ilmiah IPLBI 2014, E, 33-38.

La Roche, Claire R., Flanigan, Mary A., dan Copeland, P. K. Jr. (2010). Student Housing: Trends, Preferences and Needs. Contemporary Issues in Education Research, Vol. 3, No. 10, pp. 45-50.

Lisa, Nova Purnama (2016). Keterikatan Pekarangan terhadap Ruang Dalam berdasarkan Atribut Privasi pada Kawasan Hunian Jeron Beteng Kraton Yogyakarta. Prosiding Temu Ilmiah IPLBI, E, 149-156.

Mandasari, Dwi A. (2015). Analisis Sosio-Spasial Kost yang Mempengaruhi Preferensi Kost Mahasiswa di Lingkungan Kampus UMS. Tugas Akhir Fakultas Geografi, Universitas Muhammadiyah Surakarta.

Muchlis, Aulia F., dan Kusuma, Hanson E. (2016). Persepsi Kriteria Kenyamanan Rumah Tinggal. Prosiding Temu Ilmiah IPLBI 2016, D, 105-110.

Nijenstein, S., Haans, A., Kemperman, Astrid D. A. M., dan Borgers, Aloys W. J. (2015). Beyond Demographics: Human Value Orientation as A Predictor of Heterogeneity in Student Housing Preferences. J Hous and The Built Environ 30, 199-217.

Nurdini, Allis (2012). Refleksi Pemenuhan Kebutuhan Hunian Transien di Perkotaan: Kasus Tipologi Lokasi Hunian Sewa Mahasiswa di Kota Bandung. Prosiding Temu Ilmiah IPLBI 2012, 4, 33-36.

Oppewal, H., Poria, Y., Ravenscroft, N., dan Speller, G. (2005). Student Preferences for University Accommodation: An Application of the Stated Preference Approach. Housing, Space and Quality of Life, Chap. 9, pp. 113-124. Hampshire: Ashgate Publishers.

P., Delima (2016). Intervensi Tempat Tinggal berdasarkan Tipe Kepribadian Sebagai Bagian dari Arsitektur Hybrid. Prosiding Temu Ilmiah IPLBI 2016, D, 45-52.

P., Diah C., Ilhamdaniah, dan D., Nitih Indra K. (2012). Preferensi Konsumen Apartemen di Kota Bandung. Prosiding Temu Ilmiah IPLBI 2012, 4, 41-44.

Putra, Gierlang B., Widyasanti, Prinka V., dan Natasya (2013). Kriteria Dominan Rumah Tinggal Impian. Prosiding Temu Ilmiah IPLBI 2013, A, 21-24. 
Rachman, Riska A., dan Kusuma, Hanson E. (2015). Karakteristik Fisik-Sosial dan Kriteria Kamar yang Membuat Betah. Prosiding Temu Ilmiah IPLBI 2015, D, 53-58.

Reski, I., dan Tampubolon, Angela C. (2017). Preferensi Tipe Hunian di Kalangan Mahasiswa. Prosiding Temu Ilmiah IPLBI, G, 29-35.

Sakina, B., dan Kusuma, Hanson E. (2014). Pengaruh Kepuasan Berhuni terhadap Keinginan Pindah pada Hunian Sewa. Prosiding Temu Ilmiah IPLBI 2014, E, 27-32.

Sakina, B., dan Kusuma, Hanson E. (2015). Korespondensi antara Kualitas Hunian Sewa dan Tingkat Kepuasan Mahasiswa. Prosiding Temu Ilmiah IPLBI 2015, C, 43-50.

Sakina, B., dan Kusuma, Hanson E. (2016). Hubungan antara Jenis Hunian Sewa dan Kualitas Interaksi Sosial Mahasiswa. Prosiding Temu Ilmiah IPLBI 2016, D, 33-38.

Sari, Astri A., Kusuma, Hanson E., dan Tedjo, B. (2012). Tempat Favorit Mahasiswa sebagai Sarana Restorative. Jurnal Lingkungan Binaan Indonesia, Vol. 1, No. 1, pp. 5-18.

Triyuly, W., dan Kusuma, Hanson E. (2015). Ruang Favorit dalam Rumah. Prosiding Temu Ilmiah IPLBI 2015, E, 191-200. 